УДК 677.11.021

Г.А. ТІХОСОВА, О.О. ГОРАЧ, О.С. ЗАБРОДІНА

Херсонський національний технічний університет

\title{
ПРОБЛЕМИ ФОРМУВАННЯ КОМПОЗИЦІЙНИХ МАТЕРІАЛІВ АРМОВАНИМИ ЛУБ'ЯНИМИ ВОЛОКНАМИ
}

\author{
A. TIKHOSOVA, O. GORACH, E. ZABRODINA
}

Kherson national technical university

\section{PROBLEMS OF FORMATION OF COMPOSITIONAL MATERIALS REINFORCED WITH NATURAL FIBERS}

\section{https://doi.org/10.36910/6775-2310-5283-2021-14-25}

\begin{abstract}
Мета. Здійснити порівняльну характеристику споживних властивостей композиційних матеріалів з луб'яними волокнистими наповнювачами, одержаних на основі термореактивних та термопластичних смол.
\end{abstract}

Методика. Експериментальні дослідження споживчих властивостей технічної целюлози проводили з використанням стандартних методик і засобів вимірювання, а саме відповідно до чинних стандартів: ISO 7213-81 «Целлюлоза. Отбор проб для испьтаний. Международный стандарт», ISO 1762-74 «Целлюлоза. Метод определения содержания золь: Международный стандарт», СТ СЭВ 1491-79 «Пластмассы. Метод определения ударной вязкости по Шарпи: Международный стандарт», ISO 178:2010 «Пластмассы. Метод испытания на статический изгиб: Международный стандарт».

Результати. Проведений аналіз властивостей термопластичних та термореактивних матриць, дозволяє зробити висновок, щуо для виготовлення композиційних матеріалів армованих натуральними волокнами найбільш перспективним є використання термопластичної матриці. Перехід на термопластичні матриці, можна віднести до сучасних та найбільш перспективних напрямів в наш час, оскільки обумовлений рядом їх переваг над термореактивними.

Наукова новизна. 3 а результатами аналізу літературних джерел та експериментальних досліджень доведено переваги використання термопластичних смол для виготовлення композиційних матеріалів з луб'яними волокнистими наповнювачами, які забезпечують високі споживні характеристики композитів з меншими енерго- та матеріалозатратами.

Практична значимість. Для одержання композиційних матеріалів з луб'яними волокнистими наповнювачами рекомендується заміна термореактивної на основі фенол формальдегідної смоли на термопластичні смоли на основі поліефіру. Для використання 
фенол формальдегідних смол рекомендовано спеціальна підготовка наповнювачів, яка підвищить адгезію і високі споживні характеристики композиту.

Ключові слова: наповнювачі, волокно льону, конопель, полімерна матриця, адгезія, змочуваність, міџність, ударна в'язкість.

\section{Постановка проблеми у загальному вигляді і ії зв'язок 3 важливими} науковими та практичними завданнями. Досягнення в області термореактивних і термопластичних технологій постійно збільшуються. Хоча у кожній із них $є$ набір плюсів і мінусів, тобто, що в кінцевому підсумку визначає, який матеріал краще всього підходить для будь-якого конкретного застосування.

Проблеми формування композиційних матеріалів залежать від фізикохімічних властивостей матриці та наповнювачів. Від них залежать споживчі характеристики композитів, які чітко прописані в нормативних документах: міцність, довговічність, гнучкість, ударна вязкість та ін. [1-4].

Тому важливо становити, які чинники $є$ найбільш визначальними в створенні композиційних матеріалів 3 луб'яними волокнистими наповнювачами для формування фенол формальдегідних композиційних матеріалів. На вітчизняних підприємствах в якості волокнистих наповнювачів використовується бавовняний лінт, який імпортується 3 Узбекистану [5]. Альтернативою заміни імпортованого наповнювача $є$ луб'яні волокна 3 льону олійного та конопель. Але в композиційних полімерних матеріалах, де лляне волокно знаходиться в якості армованого матеріалу, набір застосовуваних полімерів в якості матриці обмежений. Справа у тому, що при високих температурах $\left(220^{\circ} \mathrm{C}\right)$ може початися піролітичне розкладання лляного волокна, тому частіше усього використовуються в якості матриці поліолефіни, які мають більш низькі температури розм'якшення, ніж інші полімери [6].

Аналіз останніх досліджень, у яких започатковано вирішення проблеми. Для одержання волокнистих композиційних матеріалів на даний час в Україні використовується в якості наповнювача бавовняний лінт, який $є$ імпортованою сировиною, тому заміна імпортованого наповнювача вітчизняною волокнистою сировиною - волокном льону та конопель $\epsilon$ необхідним завданням, але використання таких наповнювачів пов'язане з рядом переваг та недоліків при використанні термореактивних та термопластичних матриць, тому важливо встановити переваги та недоліки якості композиційних матеріалів при використанні тих чи інших полімерів. 
Вченим Політехнічного університету Гонконгу Hongsheng Luo було отримано нові композити на основі нанокристалів целюлози та поліакрилової кислоти (ПАК) [7]. Тим часом американськими вченими Jaewoong Lee, R. M. Broughton, S. D. Worley, T. S. Huang було вивчено механізм формування міжмолекулярних зв'язків між вибіленою бавовняною целюлозою та марамідом в процесі формування композиту [8].

Відомі роботи вчених Zhu, Huijun Zhu, James Njuguna, Hrushikesh Abhyankar, в яких описані існуючі методи модифікації природних волокнистих наповнювачів з метою підвищення адгезії волокна до полімерної матриці, проте авторами не проведено досліджень 3 модифікації природних волокнистих наповнювачів із стебел луб'яних культур на стадії приготування трести, що могло б значно здешевити процес модифікації наповнювачів перед застосуванням їх у полімерних композиційних матеріалах. Авторами передбачається розробка нової методології обробки луб'яних волокон без зміни хімічної структури целюлози.

У роботі Luyt A. S., Malunka M. Е. Висвітлені результати досліджень 3 формування полімерних композиційних матеріалів на основі короткого волокна сизалю та поліетилену. Але не проведено досліджень 3 модифікації природних волокнистих наповнювачів за допомогою хімічних композиційних препаратів задля підвищення адгезії целюлози до полімерної матриці. У роботі Behalec L., Lenfeld P., Seidl M., Bobec J., Ausperger А. Висвітлені фізичні властивості композитів 3 різними натуральними волокнами у якості наповнювачів та докладно описано технологічний процес одержання полімерних композиційних матеріалів. Недоліком цієї роботи є відсутність досліджень 3 модифікації природних волокон за допомогою хімічних композиційних препаратів.

На основі проведеного аналізу літературних джерел, можна зробити висновок, що проблемам формування композиційних матеріалів армованих луб'яними наповнювачами приділяється досить мало уваги. Для одержання волокнистих композиційних матеріалів на даний час в Україні використовується в якості наповнювача бавовняний лінт, який є імпортованою сировиною, тому заміна імпортованого наповнювача вітчизняною волокнистою сировиною - волокном льону та конопель $є$ необхідним завданням, але використання таких наповнювачів пов'язане з рядом переваг та недоліків при використанні термореактивних та термопластичних матриць, тому важливо встановити переваги та недоліки якості композиційних матеріалів при використанні тих чи інших полімерів. 
Цілі статті. Здійснити порівняльну характеристику споживних властивостей композиційних матеріалів з луб'яними волокнистими наповнювачами, одержаних на основі термореактивних та термопластичних смол.

Об'єкт дослідження. Об'єктом дослідження є споживчі властивості композиційних матеріалів з луб'яними волокнистими наповнювачами.

Методи дослідження. Експериментальні дослідження здійснювали 3 використанням стандартних методик.

\section{Виклад основного матеріалу дослідження 3 повним обгрунтуванням} отриманих наукових результатів. Основною умовою зміцнення термореактивних полімерів на основі фенол формальдегідних смол унаслідок введення в них наповнювачів $є$ повне змочування всієї поверхні наповнювача полімером. Змочування $є$ досить важливим фактором, що визначає можливість структуроутворення в полімерах. Виникнення взаємодії між наповнювачем i полімером обумовлено фізичним явищем, що називають адгезія. Як показали попередні роботи проведені на кафедрі товарознавства, стандартизації та сертифікації Херсонського національного технічного університету, луб'яні волокна мають низьку змочуваність, порівняно з бавовняним лінтом. Відомо, що змочуваність бавовняного лінту становить 120 г. Результати дослідження змочуваності лубу льону олійного та конопель після обробки у морозильній камері та після обробки у мікрохвильовій печі подано в таблиці 1.

Таблиця 1. Змочуваність лубу льону олійного та конопель

\begin{tabular}{|c|c|c|c|c|c|c|}
\hline \multirow{4}{*}{ Сировина } & \multicolumn{6}{|c|}{ Змочуваність, г } \\
\hline & \multicolumn{2}{|c|}{$\begin{array}{l}\text { після заморожування } \\
\text { у морозильній камері }\end{array}$} & \multirow{2}{*}{\multicolumn{4}{|c|}{$\begin{array}{c}\text { після обробки у мікрохвильовій } \\
\text { печі } \\
\begin{array}{c}\text { час обробки лубу у мікрохвильовій } \\
\text { печі }\end{array}\end{array}$}} \\
\hline & \multirow{2}{*}{$\begin{array}{c}\text { контрольний } \\
\text { варіант }\end{array}$} & \multirow{2}{*}{$\begin{array}{c}\text { час } \\
\text { заморожування } 7 \\
\text { діб }\end{array}$} & & & & \\
\hline & & & $8 \times \mathrm{xB}$ & $16 \times \mathrm{xB}$ & $24 \mathrm{XB}$ & $32 \times \mathrm{B}$ \\
\hline $\begin{array}{l}\text { Луб льону } \\
\text { олійного }\end{array}$ & 7,00 & 14,01 & 10,77 & 12,23 & 12,73 & 12,85 \\
\hline $\begin{array}{l}\text { Луб } \\
\text { конопель }\end{array}$ & 10,09 & 51,06 & 13,11 & 12,52 & 10,31 & 19,69 \\
\hline
\end{tabular}

Аналізуючи результати проведених досліджень, можна зробити висновок, що змочуваність після заморожування лубу льону олійного збільшилась у двічі, а лубу конопель більше ніж у п'ять разів. Змочуваність після обробки у мікрохвильовій печі лубу льону олійного зросла в середньому на 12,14 г у лубі льону олійного, а в лубі коноплі на 13,9 г. 
У результаті проведених досліджень можна зробити висновок, що застосування наповнювача з луб'яних волокон для армування термореактивних композиційних матеріалів потребує спеціальної підготовки для підвищення змочуваності і підвищення адгезіі. Таким чином, властивості композиційних матеріалів, на основі термореактивних смол армованих луб'яними волокнами, залежать не тільки від властивостей волокон і матриці, але і від взаємодії між ними. Наявність міжфазної адгезії забезпечує композитам структурну цілісність i ефективний перерозподіл навантаження між матрицею і наповнювачем. Для підвищення змочуваності нами було проведено попередня підготовка волокна, шляхом натронної варки лляного волокна, після відварювання змочуваність волокна підвищилась необробленого волокна від 12,28 г до 105,43 г, тобто збільшився майже в 10 разів. Так, одержане після відварювання волокно льону олійного має високий вміст целюлози та високий показник змочуваності, що $є$ вагомим чинником для процесу формування полімерного композиту. Таке волокно було використане для формування композитів на основі фенол формальдегідних смол з лляним волокном в якості наповнювача. В результаті було отримано композиційні матеріали 3 лляним наповнювачем, які мали фізико-механічні характеристики наближені до фізико-механічних характеристик з бавовняним лінтом. Фізико-механічні показники фенопластів на основі бавовняного лінту та відвареного лляного волокна подано в табл. 2.

Таблиця 2. Фізико-механічні показники фенопластів

\begin{tabular}{|l|c|c|}
\hline \multirow{2}{*}{\multicolumn{1}{|c|}{ Наповнювач }} & \multicolumn{2}{|c|}{ Фізико-механічна показники фенопластів } \\
\cline { 1 - 3 } & Міцність при згинанні, Мпа & Ударна в'язкість, кДж/м ${ }^{2}$ \\
\hline Волокно льону олійного & 30,1 & 10,0 \\
\hline Бавовняний лінт & 30,0 & 9,0 \\
\hline
\end{tabular}

3 таблиці видно, що показники міцності при згинанні та ударної в’язкості фенопластів 3 наповнювачем 3 волокна льону олійного навіть вищі, ніж характеристики фенопластів на основі бавовняного лінту. Таким чином, встановлено, що якість отриманих полімерних композитів дещо вища за якість композиційних матеріалів із додаванням бавовняного волокна, яке імпортується в Україну. Але така підготовка наповнювачів для формування композиційних матеріалів на основі фенол формальдегідних смол, тобто термореактивних смол, пов'язана з великими енерго- та матеріалозатратами і на нашу думку є неефективним. Тому, розглянемо можливість формування композитів 3 луб'яними волокнистими наповнювачами 3 використанням термопластичних 
смол. Досвід використання таких полімерів для формування композиційних матеріалів 3 луб'яними волокнистими наповнювачами $\epsilon$ в європейських країнах. Термопластичні композити мають дві основні переваги. Перша, полягає в тому, що термопластичні композити володіють підвищеною стійкістю до ударів в порівнянні 3 порівнянними термореактивними пластинами. В деяких випадках різниця може досягати 10-кратного значення за удароміцністю. Інша важлива перевага термопластичних композитів - це їх здатність надавати пластичність. Необроблені термопластичні смоли $€$ твердими за кімнатної температури, але коли тепло і тиск просочують армуюче волокно, відбувається фізичне зміна, проте це не хімічна реакція, яка призводить до постійних незворотних змін. Це дозволяє повторно формувати і змінювати форму термопластичних композитів.

Наприклад, якщо нагріти стрижень 3 пултрузійного термопластичного композитного матеріалу i повторно відформувати його, щоб отримати кривизну. Після охолодження крива залишиться, що неможливо для термореактивних смол. Це властивість показує величезні перспективи щодо переробки термопластичних композитних продуктів в майбутньому, коли їх початкове використання закінчиться. Недоліками термопластичних композитів, $\epsilon$ те що хоча термопластична смола в природному стані є твердою, іiі можна зробити пластичною за допомогою нагрівання, тому їі важко просочити армуючим волокном. Це є основним недоліком використання термопластичних смол. Смолу необхідно нагріти до температури плавлення і прикласти тиск для об'єднання волокон, а потім охолодити композит, який перебуває під тиском. Тому в подальших наших роботах буде проведено дослідження 3 термопластичними смолами 3 використання луб'яних волокнистих наповнювачів.

Висновки та перспективи подальших досліджень. Проведений аналіз властивостей термопластичних та термореактивних матриць, дозволяє зробити висновок, що для виготовлення композиційних матеріалів армованих натуральними волокнами найбільш перспективним $\epsilon$ використання саме термопластичної матриці. Перехід на термопластичні матриці, можна віднести до сучасних та найбільш перспективних напрямів в наш час, оскільки обумовлений рядом їх переваг над термореактивними. Композиційні матеріали на основі термопластів мають необмежений термін зберігання, скорочений у декілька разів цикл переробки. У зв'язку з тим, що даний матеріал легко розігрівається, тому процес формування деталі є менш енергоємним, особливо 
в умовах великомасштабного виробництва. Це спрощує одержання деталей складної конфігурації, підвищує продуктивність обладнання, створюючи передумови для його автоматизації. При цьому досягається повне відтворення розмірів. Композити є не токсичними, не виділяють розчинників, вибухобезпечні. Отже, технологія переробки термопластів є екологічно чистою. На сьогоднішній день, важливим $\epsilon$ те, що зазначений матеріал, можна використовувати повторно, а отже є можливість створення безвідходного виробництва.

\section{Список використаних джерел}

1. ISO 7213-81 Целлюлоза. Отбор проб для испытаний. Международный стандарт.

2. ISO 1762-74 Целлюлоза. Метод определения содержания золы. Международный стандарт.

3. СТ СЭВ 1491-79 Пластмассы. Метод определения ударной вязкости по Шарпи. Международный стандарт.

4. ISO 178:2010 Пластмассы. Метод испытания на статический изгиб. Международный стандарт.

5. Чурсина Л.А., Горач О.А., Базык В.П. Характеристика лубяного сырья для использования в техническом текстиле. Материалы и технологии. 2018. №1 (1). С. 66-72.

6. Живетин В.В., Гинзбург Л.Н. Масличный лён и его комплексное развитие. ЦНИИЛКА. Москва. 2000. С. 72-89.

7. Hongsheng Luo. Study on stimulus-responsive cellulose-based polymeric materials. The Hong Kong Polytechnic University. 2012. C. 57.

8. Jaewoong Lee, R.M. Broughton, S.D. Worley, T S. Huang. Journal of Engineered Fibers and Fabrics. Volume 2. Issue 4. 2007. C. 25.

\section{References}

1. ISO 595-79. Celljuloza. Otbor prob dlja ispytanij. Mezhdunarodnyj standart. [Cellulose. Sampling for testing. International standart].

2. ISO 1762-74. Celljuloza. Metod opredelenija soderzhanija zoly. Mezhdunarodnyj standart. [Cellulose. Method for determining the ash content. International standart].

3. ST SEV 1491-79. Plastmassy. Metod opredelenija udarnoj vjazkosti po Sharpi. Mezhdunarodnyj standart. [Plastics. Sharpie method of determining toughness. International standart].

4. ISO 178:2010. Plastmassy. Metod ispytanija na staticheskij izgib. Mezhdunarodnyj standart. [Plastics. Static bending test method. International standart].

5. Chursina L.A., Gorach O.A., Bazyk V.P. (2018). Kharakteristika lubyanogo syria dlya ispolzovaniya $\mathrm{v}$ tekhnicheskom tekstile [Characteristics of bast raw materials for use in technical textiles]. Materialy i tekhnologii [Materials and technologies]. 2018. №1 (1). P. 66-72.

6. Zhivetin V.V., Ginzburg L.N. (2000). Maslichny'i len i ego kompleksnoe razvitie [Oil flax and its complex development]. TCNIILKA [CRICALI]. 2000. P. 72-89. 
7. Hongsheng Luo. (2007). Study on stimulus-responsive cellulose-based polymeric materials. Hong Kong. The Hong Kong polytechnic university. 2012. P. 57.

8. Jaewoong Lee, Broughton R.M., Worley S.D., Huang T.S. (2007). Journal of Engineered Fibers and Fabrics. Volume 2. Issue 4. 2007. P. 25.

Purpose. To make a comparative characteristic of the consumer properties of composite materials with natural fibers obtained on the basis of thermosetting and thermoplastic resins.

Methodology. Experimental studies of consumer properties of technical cellulose using standard methods and measuring instruments, namely in accordance with current standards: ISO 7213-81 "Cellulose. Sampling for testing. International Standard”, ISO 1762-74 Cellulose. Method for determining the ash content: International Standard", ST CMEA 1491-79 Plastics. Charpy's method of determination of impact strength: International standard》, ISO 178: 2010. "Plastics. Static bending test method: International standard".

Results. The analysis of the properties of thermoplastic and thermosetting matrices allows us to conclude that for the manufacture of composite materials reinforced with natural fibers the most promising is the use of thermoplastic matrix. The use of thermoplastic matrices can be attributed to modern and most promising areas in our time because it is due to a number of their advantages over thermosetting. Composite materials based on thermoplastics have an unlimited shelf life, reduced several times the processing cycle. Due to the fact that this material is easily heated, the process of forming the part is less energy-intensive, especially in large-scale production. This simplifies the production of parts of complex configuration, increases the productivity of equipment, creating the conditions for its automation. At the same time full reproduction of the sizes is reached. Composites are non-toxic, do not emit solvents, explosionproof. Today, it is important that this material can be reused, and therefore there is a possibility of creating waste-free production.

Scientific novelty. According to the analysis of literature sources and experimental studies, the advantages of using thermoplastic resins for the manufacture of composite materials with natural fibers which provide high consumption characteristics of composites with lower energy and material consumption.

Practical significance. Replacement of thermosetting phenol-based formaldehyde resin with polyester-based thermoplastic resins is recommended for composite materials with natural fibers. For the use of phenol formaldehyde resins, special preparation of fillers is recommended, which will increase the adhesion and high consumption characteristics of the composite.

Keywords: fillers, flax fiber, hemp, polymer matrix, adhesion, wettability, strength, toughness.

Стаття рекомендована до публікаиії доктором технічних наук, професором Херсонського НТУ Чурсіною Л.А. Дата надходження в редакиію 21.01.2021 p. 